\title{
Research on the Measurement of Manufacturing Industry Integration Level of Shandong Capital City Cluster
}

\author{
Yang Zhao ${ }^{1 \text { a }}$ \\ ${ }^{1}$ Shandong Management University Jinan, China
}

\begin{abstract}
This paper analyzes the integration level of regional manufacturing industry by measuring the similarity coefficient of manufacturing industry structure and regional division index between Jinan, the capital city of Shandong province, and other cities in the region from 2012 to 2017. From 2012 to 2017, the similarity coefficient of industrial structure of Shandong capital city cluster is declining; the regional division index is rising; and the industrial transformation of Jinan in the region has made remarkable progress, which is conducive to the continuous improvement of regional integration level.
\end{abstract}

\section{INTRODUCTION}

The level of industrial integration is an important indicator to measure the level of regional integration. According to economic theory, regional division of labor is a spatial form of social division of labor, while industrial division is an organizational form of regional division of labor. Regional division of labor according to their own resource endowments can improve production efficiency. Shandong capital city cluster includes Jinan, Zibo, Dezhou, Liaocheng, Tai'an, Laiwu, and Zouping, six prefecture-level cities and one county-level city, with a total population of 30.91 million by 2017 and an area of 43000 square kilometers. Taking Jinan as the center, the provincial capital city cluster is a typical "center-periphery" spatial mode. Since the implementation of the model, regional coordination and integration has made remarkable progress, but there are still some areas leave much to be desired in the process of development. This paper attempts to analyze the regional integration progress of the capital city cluster in Shandong province from the perspective of industrial integration.

\section{The SETTING Of INDUSTRIAL INTEGRATION INDEX}

In this paper, similarity coefficient of industrial structure and index of regional division of labor are used to measure the industrial integration level of the cities in the capital city cluster of Shandong province.

\section{A. Similarity Coefficient of Industrial Structure}

The similarity coefficient of industrial structure is used to measure the similarities and differences of industrial structure between regions. If the similarity of industrial structure between regions is very high, the industrial competition between regions must be very fierce, which will lead to regional protection between regions. On the other hand, if the similarity coefficient of industrial structure between regions is too low, the industrial synergy between regions must be poor, and the industrial connection between regions will not be strong[1]. The calculation formula of industrial structure similarity coefficient is as follows:

$$
s_{i j}=\frac{\sum_{k=1}^{n} X_{i k} X_{j k}}{\sqrt{\left(\sum_{k=1}^{n} X_{i k}^{2}\right)\left(\sum_{k=1}^{n} X_{j k}^{2}\right)}}
$$

In this Formula, $S_{i j}$ is the similarity coefficient of industrial structure of two regions in the area, $\mathrm{X}_{\mathrm{ik}}, \mathrm{X}_{\mathrm{jk}}$, respectively, are the ratio of $\mathrm{k}$ industry in the industrial structure of region $\mathrm{i}$ and the ratio of $\mathrm{k}$ industry in the industrial structure of region $\mathrm{j}$. The value range of $\mathrm{S}_{\mathrm{ij}}$ is generally $0 \sim 1$. The smaller the value of $S_{i j}$ is, the more different the industrial structure is between the two regions. The closer $S_{i j}$ is to 1 , the higher the industrial structure similarity is between the two regions.

\section{B. Regional Division of Labor Index}

Since Paul R. Krugman put forward the index of regional division of labor, the index of regional division of labor has become an important index to measure regional integration. The calculation formula of regional division index is as follows[2][3]:

$$
\mathrm{S}_{j k}=\sum_{i=1}^{n}\left|\frac{q_{i k}}{q_{k}}-\frac{q_{i j}}{q_{j}}\right|
$$

In the formula, $\mathrm{S}_{\mathrm{jk}}$ is the regional division index of region $\mathrm{j}$ and region $\mathrm{k} ; \mathrm{q}_{\mathrm{k}}$ and $\mathrm{q}_{\mathrm{j}}$ are the total industrial output value of the two regions respectively, and $\mathrm{q}_{\mathrm{ik}}$ and $\mathrm{q}_{\mathrm{ij}}$ are the output value of industry $\mathrm{i}$ of the two regions respectively. $S_{\mathrm{jk}}$ value ranges from 0 to 2 . If the industrial structures of the two regions are identical, the index is 0 ; if the industrial structures of the two regions are completely different, the index is 2 .

a88092272@qq.com 


\section{THE MEASUREMENT OF INDUSTRIAL INTEGRATION LEVEL OF THE CAPITAL CITY Cluster in Shandong Province}

The data of this paper comes from the statistical yearbook of each city in the capital city cluster of Shandong province. Because Zouping is a county-level city, the scale of its manufacturing industry is too small compared with other prefecture-level cities, it is not considered in the comparison. According to the industry classification standard set by China National Bureau of Statistics,
China's manufacturing industry is divided into 31 categories. The manufacturing output value of each city in the capital city cluster of Shandong province is mainly concentrated in the top 29 categories. Due to the changes of industry classification standard over the years, this paper adjusts the classifications of some manufacturing industry to ensure the consistency of the industry statistics data over the years. After the adjustment, the manufacturing industries in the capital city cluster of Shandong province are divided into 26 categories, which are as follows:

TABLE I. CATEGORIES OF MANUFACTURING INDUSTRIES IN THE CAPITAL CITY CLUSTER OF SHANDONG PROVINCE

\begin{tabular}{|c|c|c|c|}
\hline Industry category & Industry category & Industry category & Industry category \\
\hline $\begin{array}{c}\text { Agricultural and sideline } \\
\text { food processing industry }\end{array}$ & textile industry & Furniture manufacturing & $\begin{array}{c}\text { Petroleum processing, } \\
\text { coking, and nuclear fuel } \\
\text { processing industry }\end{array}$ \\
\hline Food manufacturing & $\begin{array}{c}\text { Textile clothing, clothing } \\
\text { industry, chemical fiber } \\
\text { manufacturing industry }\end{array}$ & $\begin{array}{c}\text { Paper making and paper } \\
\text { manufacturing }\end{array}$ & $\begin{array}{c}\text { Chemical raw materials and } \\
\text { chemical products } \\
\text { manufacturing industry }\end{array}$ \\
\hline $\begin{array}{c}\text { Wine, beverage, and refined } \\
\text { tea manufacturing }\end{array}$ & $\begin{array}{c}\text { Leather, fur, feather and their } \\
\text { products, and footwear } \\
\text { industry }\end{array}$ & $\begin{array}{c}\text { Printing and recording media } \\
\text { reproduction industry }\end{array}$ & $\begin{array}{c}\text { Pharmaceutical } \\
\text { manufacturing }\end{array}$ \\
\hline $\begin{array}{c}\text { Tobacco products industry } \\
\text { bood processing and wood, } \\
\text { grass products industry } \\
\text { industry and beauty, sports } \\
\text { and entertainment products } \\
\text { manufacturing industry }\end{array}$ & $\begin{array}{c}\text { Rubber and plastic products } \\
\text { industry }\end{array}$ \\
\hline $\begin{array}{c}\text { Nonmetallic mineral products } \\
\text { industry }\end{array}$ & $\begin{array}{c}\text { General equipment } \\
\text { manufacturing }\end{array}$ & $\begin{array}{c}\text { Nonferrous metal smelting } \\
\text { and rolling industry }\end{array}$ & $\begin{array}{c}\text { Transportation equipment } \\
\text { manufacturing industry }\end{array}$ \\
\hline $\begin{array}{c}\text { Ferrous metal smelting and } \\
\text { rolling industry }\end{array}$ & $\begin{array}{c}\text { Special equipment } \\
\text { manufacturing industry }\end{array}$ & Metal products industry & $\begin{array}{c}\text { Manufacturing of computer, } \\
\text { communication and other } \\
\text { electronic equipment }\end{array}$ \\
\hline $\begin{array}{c}\text { Electrical machinery and } \\
\text { equipment manufacturing } \\
\text { industry }\end{array}$ & Instrument manufacturing \\
industry & & &
\end{tabular}

\section{A. Calculation of Similarity Coefficient of Industrial Structure}

This paper measures the industrial structure similarity coefficient of the manufacturing industries of Jinan city cluster from 2012 to 2017 . The provincial capital city cluster is a regional spatial structure with Jinan as the center and other cities as the periphery. Therefore, the similarity coefficient of industrial structure is mainly used to calculate the industrial structure similarity between Jinan and the peripheral cities. The results are as follows:

TABLE II. INDUSTRIAL STRUCTURE SIMILARITY

\begin{tabular}{|c|c|c|c|c|c|c|}
\hline & $\mathbf{2 0 1 2}$ & $\mathbf{2 0 1 3}$ & $\mathbf{2 0 1 4}$ & $\mathbf{2 0 1 5}$ & $\mathbf{2 0 1 6}$ & $\mathbf{2 0 1 7}$ \\
\hline Zibo & 0.65 & 0.61 & 0.62 & 0.64 & 0.59 & 0.48 \\
\hline Tai'an & 0.80 & 0.80 & 0.81 & 0.89 & 0.85 & 0.66 \\
\hline Dezhou & 0.63 & 0.68 & 0.71 & 0.91 & 0.86 & 0.69 \\
\hline Liaocheng & 0.57 & 0.59 & 0.60 & 0.83 & 0.80 & 0.63 \\
\hline Laiwu & 0.43 & 0.43 & 0.47 & 0.42 & 0.39 & 0.26 \\
\hline
\end{tabular}




\section{B. Calculation of the Regional Division of Labor Index}

The index of regional division of labor between Jinan, the center of the capital city cluster of Shandong province, and the surrounding cities is calculated. The results are as follows:

TABLE III. INDEX OF REGIONAL DIVISION

\begin{tabular}{|c|c|c|c|c|c|c|}
\hline & $\mathbf{2 0 1 2}$ & $\mathbf{2 0 1 3}$ & $\mathbf{2 0 1 4}$ & $\mathbf{2 0 1 5}$ & $\mathbf{2 0 1 6}$ & $\mathbf{2 0 1 7}$ \\
\hline Zibo & 0.82 & 0.85 & 0.84 & 0.87 & 0.88 & 0.97 \\
\hline Tai'an & 0.65 & 0.66 & 0.66 & 0.62 & 0.63 & 0.75 \\
\hline Dezhou & 0.83 & 0.78 & 0.75 & 0.68 & 0.68 & 0.70 \\
\hline Liaocheng & 0.88 & 0.84 & 0.79 & 0.76 & 0.76 & 0.89 \\
\hline Laiwu & 1.28 & 1.15 & 1.04 & 1.03 & 1.10 & 1.37 \\
\hline
\end{tabular}

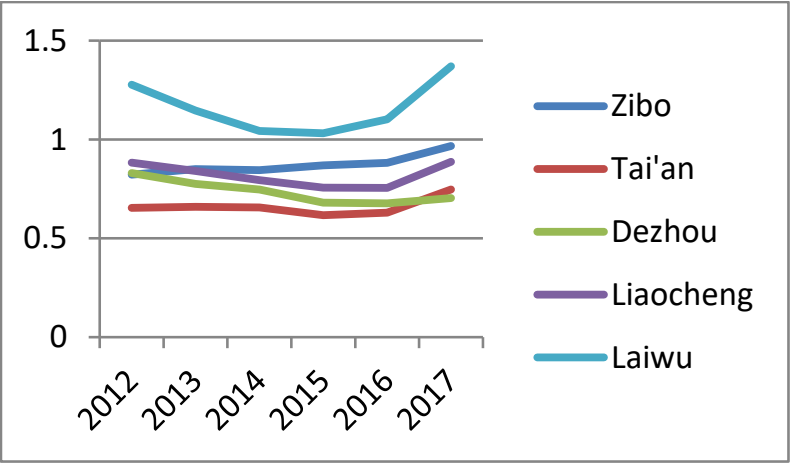

Figure 2. index of regional division

As shown in the figure 2 above, according to the calculation of regional division of labor index, before 2015, Laiwu had the largest difference in industrial structure from Jinan and other cities in the provincial capital city cluster, and Tai'an had the smallest difference. Besides, the difference remained stable before 2015 . However, since 2016, the difference in industrial structure between cities has increased, which is more obvious in Laiwu.

\section{AnALysis on the Difference of MANUFACTURING INDUSTRIAL STRUCTURE IN the Capital City Cluster of Shandong PROVINCE}

The industrial structures of each city in the capital city cluster of Shandong province are very different. The industrial structure of Jinan is relatively balanced, with 26 manufacturing industries involved in the structure. In 2012, the industry with the largest output value is transportation equipment manufacturing, accounting for $15.49 \%$ of the total. In 2017 , its output value increased to $21.88 \%$, while the proportion of other industries is less than $10 \%[4]$.

Zibo's manufacturing industry was very concentrated, with chemical raw materials and chemical products manufacturing industry accounting for $27 \%$, petroleum processing, coking and nuclear fuel processing industry accounting for $14.38 \%$, and non-metallic mineral products industry accounting for $15.96 \%$ in 2012 . These three industries totally accounted for $57.34 \%$. In 2017 , the share of the three industries hardly changed.
As for Tai'an, it has no manufacturing industry with special advantage, only some industries, such as chemical raw materials and chemical products manufacturing, general equipment manufacturing, and non-metallic mineral products industry, accounted for slightly $10 \%$ of the output value.

Dezhou's dominant manufacturing industries are agricultural and sideline food processing industry, and chemical raw materials and chemical products manufacturing industry, with the output value accounting for $13.64 \%$ and $11.5 \%$ respectively in 2012 . In 2017 , the advantages of agricultural and sideline food processing industry were more obvious, with the output value accounting for $13.46 \%$, while the output value of other industries accounting for less than $10 \%$.

Liaocheng's dominant manufacturing industries are textile industry, non-ferrous metal smelting and rolling processing industry. In 2012, the output value of these two industries accounted for $10.41 \%$ and $17.3 \%$. In 2017 , the proportion of textile industry, non-ferrous metal smelting industry and rolling processing industry decreased slightly, accounting for $10.84 \%$ and $15.49 \%$ respectively; and the proportion of general equipment manufacturing industry increased slightly, accounting for $11.88 \%$.

In the capital city cluster of Shandong province, Laiwu has the simplest industrial structure of manufacturing industry, and almost all its output value of manufacturing industry is concentrated in ferrous metal smelting and rolling processing industry. In 2012, ferrous metal smelting and calendering industry accounted for $69 \%$ of Laiwu's manufacturing output value; in 2017, it accounted for $68 \%$; many other industries' output value in Laiwu was 0 , only agricultural and sideline food processing industry accounted for slightly more than $5 \%$.

The following table shows the top three industries in manufacturing output value of Shandong capital city cluster in 2012 and 2017: 
TABLE IV. TOP THREE MANUFACTURING INDUSTRIES IN 2012

Top three manufacturing industries in 2012

\begin{tabular}{|c|c|c|c|c|c|c|c|c|c|c|c|}
\hline \multicolumn{2}{|c|}{ Jinan } & \multicolumn{2}{|l|}{ Zibo } & \multicolumn{2}{|c|}{ Tai' an } & \multicolumn{2}{|c|}{ Dezhou } & \multicolumn{2}{|c|}{ Liaocheng } & \multicolumn{2}{|c|}{ Laiwu } \\
\hline industry & Ratio & industry & Ratio & industry & Ratio & industry & Ratio & industry & Ratio & industry & Ratio \\
\hline $\begin{array}{l}\text { Transport } \\
\text { ation } \\
\text { equipment } \\
\text { manufactu } \\
\text { ring } \\
\text { industry }\end{array}$ & 15. 49 & \begin{tabular}{|c} 
Chemical \\
raw \\
materials \\
and \\
chemical \\
products \\
manufactur \\
ing \\
industry \\
\end{tabular} & 20 & \begin{tabular}{|c} 
Chemical \\
raw \\
materials \\
and \\
chemical \\
products \\
manufactur \\
ing \\
industry \\
\end{tabular} & 11.68 & $\begin{array}{c}\text { Agricultu } \\
\text { ral and } \\
\text { sideline } \\
\text { food } \\
\text { processin } \\
\text { g } \\
\text { industry }\end{array}$ & 13.6 & $\begin{array}{l}\text { Non } \\
\text { ferrous } \\
\text { metal } \\
\text { smelting } \\
\text { and } \\
\text { rolling } \\
\text { industry }\end{array}$ & 17. 3 & $\begin{array}{l}\text { Ferrous } \\
\text { metal } \\
\text { smelting } \\
\text { and } \\
\text { rolling } \\
\text { industry }\end{array}$ & 69 \\
\hline $\begin{array}{l}\text { Ferrous } \\
\text { metal } \\
\text { smelting } \\
\text { and } \\
\text { rolling } \\
\text { industry }\end{array}$ & 9.4 & $\begin{array}{c}\text { Nonmetalli } \\
\text { c mineral } \\
\text { products } \\
\text { industry }\end{array}$ & 15.9 & $\begin{array}{c}\text { General } \\
\text { equipment } \\
\text { manufactur } \\
\text { ing }\end{array}$ & 11.17 & $\begin{array}{c}\text { Chemical } \\
\text { raw } \\
\text { materials } \\
\text { and } \\
\text { chemical } \\
\text { products } \\
\text { manufactu } \\
\text { ring } \\
\text { industry }\end{array}$ & 11.5 & $\begin{array}{l}\text { textile } \\
\text { industry }\end{array}$ & 10.4 & $\begin{array}{l}\text { Chemical } \\
\text { raw } \\
\text { material } \\
\text { s and } \\
\text { chemical } \\
\text { products } \\
\text { manufact } \\
\text { uring } \\
\text { industry }\end{array}$ & 4. 26 \\
\hline $\begin{array}{l}\text { Petroleum } \\
\text { processin } \\
\text { g, coking } \\
\text { and } \\
\text { nuclear } \\
\text { fuel } \\
\text { processin } \\
\text { g } \\
\text { industry }\end{array}$ & 8.95 & \begin{tabular}{|c} 
Petroleum \\
processing \\
, coking \\
and \\
nuclear \\
fuel \\
processing \\
industry
\end{tabular} & 14.38 & $\mid \begin{array}{c}\text { Nonmetalli } \\
\text { c mineral } \\
\text { products } \\
\text { industry }\end{array}$ & 9.45 & $\begin{array}{c}\text { Nonmetal1 } \\
\text { ic } \\
\text { mineral } \\
\text { products } \\
\text { industry }\end{array}$ & 9.46 & $\begin{array}{c}\text { Transport } \\
\text { ation } \\
\text { equipment } \\
\text { manufactu } \\
\text { ring } \\
\text { industry }\end{array}$ & 9.18 & $\begin{array}{l}\text { Metal } \\
\text { products } \\
\text { industry }\end{array}$ & 3.9 \\
\hline
\end{tabular}

TABLE V. TOP THREE MANUFACTURING INDUSTRIES IN 2017

\begin{tabular}{|c|c|c|c|c|c|c|c|c|c|c|c|}
\hline \multicolumn{12}{|c|}{ Top three manufacturing industries in 2017} \\
\hline \multicolumn{2}{|l|}{ Jinan } & \multicolumn{2}{|c|}{ Zibo } & \multicolumn{2}{|c|}{ Tai'an } & \multicolumn{2}{|c|}{ Dezhou } & \multicolumn{2}{|c|}{ Liaocheng } & \multicolumn{2}{|c|}{ Laiwu } \\
\hline industry & Ratio & industry & Ratio & industry & Ratio & industry & Ratio & industry & Ratio & industry & Ratio \\
\hline $\begin{array}{c}\text { Transportat } \\
\text { ion } \\
\text { equipment } \\
\text { manufacturi } \\
\text { ng industry }\end{array}$ & 21.88 & $\begin{array}{c}\text { Chemical } \\
\text { raw } \\
\text { material } \\
\text { s and } \\
\text { chemical } \\
\text { products } \\
\text { manufact } \\
\text { uring } \\
\text { industry }\end{array}$ & 28.24 & $\begin{array}{c}\text { General } \\
\text { equipmen } \\
\mathrm{t} \\
\text { manufact } \\
\text { uring }\end{array}$ & 10.97 & $\mid \begin{array}{c}\text { Agricult } \\
\text { ural and } \\
\text { sideline } \\
\text { food } \\
\text { processi } \\
\text { ng } \\
\text { industry }\end{array}$ & 13.45 & \begin{tabular}{|c} 
Non \\
ferrous \\
metal \\
smelting \\
and \\
rolling \\
industry
\end{tabular} & 15.49 & $\begin{array}{c}\text { Ferrous } \\
\text { metal } \\
\text { smelting } \\
\text { and } \\
\text { rolling } \\
\text { industry }\end{array}$ & 68.55 \\
\hline $\begin{array}{l}\text { Manufacturi } \\
\text { ng of } \\
\text { computer, } \\
\text { communicati } \\
\text { on and } \\
\text { other } \\
\text { electronic } \\
\text { equipment }\end{array}$ & 10.05 & $\begin{array}{c}\text { Petroleu } \\
\mathrm{m} \\
\text { processi } \\
\text { ng, cokin } \\
\text { g and } \\
\text { nuclear } \\
\text { fuel } \\
\text { processi } \\
\text { ng } \\
\text { industry }\end{array}$ & 16.62 & $\begin{array}{c}\text { Nonmetal } \\
\text { lic } \\
\text { mineral } \\
\text { products } \\
\text { industry }\end{array}$ & 10.7 & $\begin{array}{c}\text { Chemical } \\
\text { raw } \\
\text { material } \\
\text { s and } \\
\text { chemical } \\
\text { products } \\
\text { manufact } \\
\text { uring } \\
\text { industry }\end{array}$ & 9.85 & $\begin{array}{c}\text { General } \\
\text { equipmen } \\
t \\
\text { manufact } \\
\text { uring }\end{array}$ & 11.88 & $\begin{array}{l}\text { Agricult } \\
\text { ural and } \\
\text { sideline } \\
\text { food } \\
\text { processi } \\
\text { ng } \\
\text { industry }\end{array}$ & 5.43 \\
\hline $\begin{array}{c}\text { General } \\
\text { equipment } \\
\text { manufacturi } \\
\text { ng }\end{array}$ & 9.08 & $\begin{array}{c}\text { Nonmetal } \\
\text { lic } \\
\text { mineral } \\
\text { products } \\
\text { industry }\end{array}$ & 12.5 & $\begin{array}{c}\text { Chemical } \\
\text { raw } \\
\text { material } \\
\text { s and } \\
\text { chemical } \\
\text { products } \\
\text { manufact } \\
\text { uring } \\
\text { industry }\end{array}$ & 10 & $\begin{array}{c}\text { General } \\
\text { equipmen } \\
t \\
\text { manufact } \\
\text { uring }\end{array}$ & 8.85 & $\begin{array}{l}\text { textile } \\
\text { industry }\end{array}$ & 10.84 & $\begin{array}{c}\text { Chemical } \\
\text { raw } \\
\text { material } \\
\text { s and } \\
\text { chemical } \\
\text { products } \\
\text { manufact } \\
\text { uring } \\
\text { industry }\end{array}$ & 3.53 \\
\hline
\end{tabular}

\section{Analysis on the Tendency of Change}

If we use the median 0.5 of the similarity coefficient of industrial structure to distinguish, Jinan, the center of provincial capital city cluster, has a high similarity in industrial structure with other cities except Laiwu. The high similarity of industrial structure means that there is a competitive relationship in industrial structure among Jinan, the center of the region, and the surrounding cities. The similarity coefficient of manufacturing industrial structure between Jinan, Dezhou and Tai'an reached 90\% 
in 2015, which means that there is a strong competitive relationship among the three cities[5].

From the perspective of regional integration, the optimal mode of industrial structure for central city and peripheral cities should realize reasonable regional division of labor and cooperation according to their respective resource endowments, so as to realize the most effective use of regional resources. When there is no trade barrier in a region and the transportation cost is very low, industries tend to gather in one area. The industrial similarity between Jinan and Laiwu is very low, which shows that the merger of Jinan and Laiwu is a correct decision. The lower manufacturing industry similarity means that Jinan and Laiwu have less competition in manufacturing industries and they can compensate for each other, which is conducive to the further development of regional integration.

Since 2015, the similarity of industrial structure between Jinan and other cities in the region has been decreasing, and the regional division index has been improving. The reason behind this is that the industrial transformation of Jinan is accelerating. From table 4 and table 5, it can be found that in 2012, the top three manufacturing industries in Jinan are transportation equipment manufacturing, ferrous metal smelting and rolling processing, petroleum processing, coking and nuclear fuel processing. However, by 2017, the top three industries have become transportation equipment manufacturing, computer, communication and other electronic equipment manufacturing, and general equipment manufacturing, which shows the industrial upgrading of Jinan has started. However, that of other cities in the region is not obvious. Generally speaking, the improvement of regional division of labor is conducive to the development of regional integration.

\section{REFERENCES}

1. Griffith E.Testing the von Thunen theory in Uruguay[J].Geographical Review,1973,63:500-516.

2. Krugman P.Geography and Trade [M].Leuven University Press, 1991.

3. Krugman P.Increasing Returns and Economic Geography[J].Journal of Political Economy,1991(99):483-499.

4. Fujita,M and Thisse,J.F.Economics of Agglomerution:Cites,Industrial Location and Regional Growth [M].Cambridge:Cambridge University press, 2002.

5. Noughton,Barry.How Much Can Regional Integration Do to Unify China's Market,University of California at San Diego Mimeo,1999. 